\title{
HABITAT AFFINITIES OF RODENTS IN NORTHEASTERN NEVADA RANGELAND COMMUNITIES
}

\author{
J. Kent McAdoo ${ }^{1}$, Mack R. Barrington ${ }^{2}$, and Mark A. Ports ${ }^{3}$
}

\begin{abstract}
From May 1978 through September 1980, baseline data for rodent populations were collected by livetrapping in the Saval Ranch area of northeastern Nevada. The objectives of this study were to determine species composition and relative abundance of rodents for the various range sites. The 3 most abundant and uniformly distributed species were deer mice (Peromyscus maniculatus), Great Basin pocket mice (Perognathus parvus), and least chipmunks (Neotamias minimus). Relative abundance indices and densities reported for most species were similar to those reported in other multiyear studies at similar sites. The composition and relative abundance / density of rodent species was variable among habitats and over time. Diverse rodent species within the sagebrush ecosystem have commensurately diverse habitat requirements that should be considered when vegetation management is planned. Annual population fluctuations and differences among similar habitats should be considered when researchers propose to test rodent population responses to livestock grazing or other habitat treatments.
\end{abstract}

Key words: rodents, sagebrush-obligate mammals, small mammal habitat affinities, rangeland.

From May 1978 through September 1980, baseline data for rodent populations were collected in the Saval Ranch area of northeastern Nevada. The objectives of this study were to determine composition and relative abundance of rodents for the various range sites. This work was completed within the context of a large interdisciplinary research project evaluating the impacts of various livestock grazing systems and rangeland seedings, a cooperative effort involving the University of Nevada Reno, USDA Agricultural Research Service, and Bureau of Land Management (BLM). This information was originally reported in annual progress reports and is being published here to provide background and baseline information, particularly for sagebrush-obligate and sagebrushassociated rodent species.

The Saval Ranch lies within the "sagebrush (Artemisia spp.) steppe” region, as defined by West (1983). Most of the study area is dominated by the vegetation zones described by Tueller (1975) as "northern desert shrub" and "mountain brush," with sagebrush being the dominant shrub. Sagebrush-grass communities vary markedly on the landscape, but to one degree or another provide food, thermal cover, escape routes, and rearing sites for a variety of vertebrate wildlife species (McAdoo and Klebenow 1979).

The literature on western rangeland fauna has focused comparatively little attention on the impacts, benefits, and ecosystem interactions of rodents. According to O'Farrell (1974), sagebrush communities of the Great Basin have been particularly neglected in terms of rodent studies. Instead of just "competing for forage" as they have been characterized in the past, rodents are important ecosystem stabilizing and sustaining agents and thus are essential to the maintenance of healthy rangeland ecosystems (McAdoo et al. 2004b). The interactions of these animals in rangeland ecosystems are very complex.

\section{STUdy AREA}

The Saval Ranch is located in northeastern Nevada, approximately 40 miles $(67 \mathrm{~km})$ north of Elko. The ranch unit consisted of approximately 23,650 ha, including 11,220 ha managed by the BLM, 6810 ha managed by the USDA Forest Service, and 5610 ha in private ownership. The latter was comprised primarily of hay meadows and crested wheatgrass (Agropyron desertorum) seedings. The study area ranged in elevation from $1780 \mathrm{~m}$ at the

\footnotetext{
${ }^{1}$ University of Nevada Cooperative Extension, 701 Walnut Street, Elko, NV 89801.

${ }^{2}$ Oregon Department of Agriculture, Natural Resources Division, 635 Capitol St. NE, Salem, OR 97301.

${ }^{3}$ Great Basin College, 1500 College Parkway, Elko, NV 89801.
} 
eastern toe of the alluvial fan to $2470 \mathrm{~m}$ at the ridgeline of the Independence Mountains. Major landforms of the study area included mountains, mountain ridges, streams, canyons, and cut alluvial fans (Armentrout and Barrington 1980). Dominant vegetation species by range site are reported in Table 1 . Generally speaking, an increase in the precipitation zone (pz) descriptor corresponded directly with increased elevation. Livestock grazing (by cattle) was the primary land use during the study period and historically since the 1880 s.

Upland vegetation at lower elevations (1780$2040 \mathrm{~m}$ ) was dominated by big sagebrush (Artemisia tridentata wyomingensis and A. tridentata tridentata)-grass-forb communities on loamy soils, and little sagebrush and alkali sagebrush (A. arbuscula arbuscula and A. arbuscula longiloba)-grass-forb communities on claypan soils. Other shrubs included green rabbitbrush (Chrysothamnus viscidiflorus), rubber rabbitbrush (C. nauseosus), and antelope bitterbrush (Purshia tridentata). Common grass species were bluebunch wheatgrass (Agropyron spicatum), Nevada bluegrass (Poa nevadensis), basin wildrye (Leymus cinereus), bottlebrush squirreltail (Elymus elymoides), Idaho fescue (Festuca idahoensis), and Thurber needlegrass (Achnatherum thurberianum), with scattered cheatgrass (Bromus tectorum) in some areas.

Upland vegetation at higher elevations (above $2040 \mathrm{~m}$ ) was dominated by mountain brush communities (Tueller 1975), with mountain big sagebrush (A. tridentata vaseyana), black sagebrush (A. nova), serviceberry (Amelanchier alnifolia), mountain snowberry (Symphoricarpos oreophilus), and chokecherry (Prunus virginiana) as the dominant shrubs. Grasses included basin wildrye, bluebunch wheatgrass, and Idaho fescue. "Snowpockets" on concave north-facing slopes were dominated by lupine (Lupinus sp.), with numerous other forb species found throughout the upper elevations. Some small isolated pockets on north-facing slopes included relict populations of limber pine (Pinus flexilis).

Meadows at lower elevations were dominated by grasses and grass-like species, including basin wildrye, western wheatgrass (Pascopyrum smithii), meadow barley (Hordeum brachyantherum), beardless wildrye (Leymus triticoides), sedges (Carex spp.), and wiregrass (Juncus balticus). Various willow species (Salix spp.) and Wood's rose (Rosa woodsii) occurred in some portions of these meadows. Riparian habitat along streams at upper elevations included quaking aspens (Populus tremuloides), willow, and mountain brome (Bromus carinatus), as well as other grasses and numerous forb species.

\section{Methods}

Rodent population data were collected from range sites (Table 1) that were based on soil type, vegetation composition, and precipitation zone (pz) as delineated by USDA Natural Resource Conservation Service Order III Soil Surveys. Representative transects within these range sites were sampled by a BLM Soil Vegetation Inventories Method (SVIM) team in 1978- 1979 to determine species composition and condition class. Data collected along each SVIM transect included a minimum of 200 step-points, 3 vegetation characterization plots, and 10 vegetation weight estimate plots (with 2 per transect clipped and weighed). Size of vegetation characterization and weight estimation plots was $1 \mathrm{~m}^{2}$ for upland vegetation and $0.1 \mathrm{~m}^{2}$ for riparian vegetation. To ensure ideal conditions for plant diversity and identification, the transects were sampled from June through August (Armentrout and Barrington 1980).

The areas selected for sampling rodent species were located along vegetation transects within these range sites. These areas were sampled for 4 consecutive nights with livetrap lines $360 \mathrm{~m}$ in length and consisting of 25 stations spaced $15 \mathrm{~m}$ apart. One Sherman mouse trap was placed at each station and 1 Tomahawk squirrel trap at alternate stations (within those range sites where squirrels were obviously present as indicated by sightings and burrows). Traps were baited with rolled oats and checked twice daily (morning and evening). All animals caught were eartagged, sexed, weighed, and released. The mean numbers of rodents trapped per line in each habitat site were used as minimum estimates of relative abundance (number per 100 trap-nights for all cricetid species, microtine species, and chipmunks; number per 52 trap-nights for ground squirrels) for each site. Our original intent was to use a mark-recapture method for determining rodent numbers, regressing the daily recapture rate on the number previously 
TABLE 1. Range sites sampled with rodent traplines during the 1978-1980 baseline data collection at the Saval Ranch, northeastern Nevada.

\begin{tabular}{|c|c|c|}
\hline Range Site & Dominant Vegetation Species & Traplines \\
\hline Loamy $8-10^{\prime \prime} \mathrm{pz}^{\S}$ & $\begin{array}{l}\text { Wyoming big sagebrush, green rabbitbrush, Thurber needlegrass, } \\
\text { bottlebrush squirreltail, forbs }\end{array}$ & 8 \\
\hline Loamy $10-12^{\prime \prime} \mathrm{pz}$ & $\begin{array}{l}\text { Wyoming or mountain big sagebrush, bitterbrush, lupine sp., basin wildrye, } \\
\text { forbs }\end{array}$ & 3 \\
\hline Loamy bottom & $\begin{array}{l}\text { Basin big sagebrush, rubber rabbitbrush, bitterbrush, basin wildrye, } \\
\text { Nevada bluegrass, forbs }\end{array}$ & 7 \\
\hline Loamy slopes $10-14^{\prime \prime} \mathrm{pz}$ & $\begin{array}{l}\text { Mountain and/or Wyoming big sagebrush, green rabbitbrush, bitterbrush, } \\
\text { snowberry, forbs }\end{array}$ & 10 \\
\hline Loamy slopes $14-18^{\prime \prime} \mathrm{pz}$ & $\begin{array}{l}\text { Chokecherry, mountain big sagebrush, bluebunch wheatgrass, basin wildrye, } \\
\text { forbs }\end{array}$ & 3 \\
\hline South slopes $12-18^{\prime \prime} \mathrm{pz}$ & $\begin{array}{l}\text { Mountain big sagebrush, bitterbrush, green rabbitbrush, serviceberry, } \\
\text { bluebunch wheatgrass, forbs }\end{array}$ & 8 \\
\hline North slopes $12-18^{\prime \prime} \mathrm{pz}$ & Serviceberry, Idaho fescue, forbs & 1 \\
\hline Upland browse $12-16^{\prime \prime} \mathrm{pz}$ & Serviceberry, mountain big sagebrush, Idaho fescue, basin wildrye, forbs & 2 \\
\hline Claypan $10-12^{\prime \prime} \mathrm{pz}$ & Alkali sagebrush, bottlebrush squirreltail, Nevada bluegrass, forbs & 2 \\
\hline Claypan $12-16^{\prime \prime} \mathrm{pz}$ & Little sagebrush, green rabbitbrush, cheatgrass, Idaho fescue, forbs & 1 \\
\hline Cobbly claypan $8-12^{\prime \prime} \mathrm{pz}$ & $\begin{array}{l}\text { Alkali sagebrush, little sagebrush, green rabbitbrush, Idaho fescue, } \\
\text { bottlebrush squirreltail, forbs }\end{array}$ & 2 \\
\hline Mountain ridges & Little sagebrush, black sagebrush, Idaho fescue, bottlebrush squirreltail, forbs & 3 \\
\hline Aspen thicket & Aspen, serviceberry, snowberry, mountain brome, forbs & 3 \\
\hline Riparian aspen woodland & Aspen, willow, forbs & 4 \\
\hline Upland aspen woodland & Aspen, forbs & 4 \\
\hline Snowpocket & Lupine sp. & 1 \\
\hline Crested wheatgrass & Crested wheatgrass, Wyoming big sagebrush & 5 \\
\hline Dry floodplain & $\begin{array}{l}\text { Rubber rabbitbrush, basin big sagebrush, basin wildrye, western wheatgrass, } \\
\text { forbs }\end{array}$ & 2 \\
\hline Wet meadow & Willow spp., basin wildrye, sedge spp., wiregrass, meadow barley, forbs & 19 \\
\hline Dry meadow & Beardless wildrye, Nevada bluegrass, Wood's rose, forbs & 6 \\
\hline Hay meadow & $\begin{array}{l}\text { Willow spp., basin wildrye, sedge spp., wiregrass, meadow barley, forbs, } \\
\text { introduced mesic grasses }\end{array}$ & 7 \\
\hline TOTAL & & 101 \\
\hline
\end{tabular}

$\S_{\mathrm{pz}}=$ precipitation zone

caught (Hayne 1949). However, because recapture rates for some species were low enough that calculated abundance was often less than the actual number of 1st-time captures, we used number of 1st-time captures for minimum population estimates.

Because of small sample size during the 1978 start-up period, the 15 traplines in 1978 were considered collectively with the 37 traplines in 1979 for comparison with the 49 traplines in 1980. We used Student's $t$ test to determine significant differences $(P<0.05)$ between relative abundance of rodents in 19781979 versus 1980 .

To better quantify rodent populations and test for significant differences among range sites, we calculated densities for range sites where several lines were trapped. This was done only for the combined 1978-1979 data because of relatively low rodent populations in
1980. We then computed the mean densities for the range sites or composite range sites being compared. Densities were calculated by dividing by the area trapped for each line. Areas trapped along each line were computed from the following formula described by Brant (1962):

$$
A=\pi r^{2}+2 r l
$$

where $A$ is the area trapped, $r$ is the average distance moved by recaptured rodents, and $l$ is the length of the trapline $(360 \mathrm{~m})$. Because of the low recapture rates of many rodent species, average movement $(r)$ was calculated by pooling and averaging movements of several species within a given range site. Since large diurnal species (i.e., chipmunks) range more widely than cricetid and microtine rodents, movements were pooled according 
to these categories. The single exception was deer mice (Peromyscus maniculatus). Because of high abundance and high recapture rates, movements for this species were averaged separately. These calculated densities were then averaged to obtain a mean density for the composite range site. We used 1-way analysis of variance and Duncan's multiple range tests to check for significant differences $(P<0.05)$ in rodent densities among these range sites.

\section{REsUlts}

During the 3-year period, we captured 2285 individual rodents in 17,028 trap-nights. This total included a few nonstandard traplines in areas known as "special habitat features," like rock outcrops, seeps, springs, stock water ponds, and so forth (Armentrout and Barrington 1980). A total of 21 rodent species have been identified within the study area, and 14 of these were trapped during the study period. Three other species were trapped in corollary or subsequent studies: the Uintah chipmunk (Neotamias umbrinus), Botta's pocket gopher (Thomomys bottae), and western harvest mouse (Reithrodontomys megalotis). Rodent species seen but not trapped included muskrats (Ondatra zibethica), beaver (Castor canadensis), yellow-bellied marmots (Marmota flaviventris), and porcupines (Erethizon dorsatum). Other small mammal species recorded within the study area include the water shrew (Sorex palustris) and 3 upland shrew species: Merriam's shrew $(S$. merriami), vagrant shrew $(S$. vagrans), and montane shrew (S. monticolus; Ports and McAdoo 1986).

\section{Relative Abundance among Range Sites}

During the entire inventory period, deer mice were the most abundant and eurytopic rodent species. They were the most numerous species in all but the hay meadow range site (Table 2). In 16 range sites, deer mice made up $\geq 50 \%$ of all rodents trapped. The Great Basin pocket mouse (Perognathus parvus), another nocturnal species, was also widespread and occurred in 15 of the 21 range sites. This species was most abundant in claypan and mountain ridge range sites dominated by alkali sagebrush and little sagebrush, respectively. Great Basin pocket mice were also common in crested wheatgrass seedings (Table 2). This species was noticeably absent or recorded at low levels in the more mesic range sites.

The least chipmunk (Neotamias minimus) was the most abundant and widespread diurnal rodent (occurring in 15 range sites) throughout the inventory period. This species was most abundant in the moist floodplain and north slopes $12-18^{\prime \prime} \mathrm{pz}$ range sites (Table 2), both dominated by big sagebrush. Belding's ground squirrels (Spermophilus beldingi) and golden-mantled ground squirrels (S. lateralis) were each found in 12 range sites ranging from upper to lower elevations and overlapping in 8 of these.

We also trapped many other species during the 3-year period. Ord's kangaroo rats (Dipodomys ordii) occupied 6 range sites, while northern grasshopper mice (Onychomys leucogaster) and western jumping mice (Zapus princeps) each occurred in 5 range sites. Montane voles (Microtus montanus) and long-tailed voles (M. longicaudus) were found in 4 meadow-like and 2 aspen-dominated range sites, respectively. Long-tailed voles were caught only during 1980. Four other species were limited in distribution to 3 range sites or fewer (Table 2). Sagebrush voles (Lemmiscus curtatus) were found in the loamy bottom, claypan 10-12"pz, and crested wheatgrass range sites (the only range site where they were detected in 19781979). Richardson's ground squirrels (Spermophilus richardsonii) were limited to aspen thickets and wet meadows, while Townsend's ground squirrels (S. townsendii) were recorded in the claypan 10-12"pz and wet meadow range sites. Bushy-tailed woodrats (Neotoma cinerea) were trapped only in the riparian aspen woodland range site and rock outcrops. For the entire inventory period, rodent numbers were highest in riparian aspen woodland (30.5 per line) and lowest in dry meadows and hay meadows, with 4.4 and 4.1 per trapline, respectively (Table 2 ).

\section{Annual Fluctuations in Relative Abundance}

Our comparison of the 1978-1979 data with 1980 data was useful for examination of overall rodent abundance and species composition. However, valid statistical comparisons of rodent abundance among the various range sites (all years combined) is complicated by an apparent decrease in rodent populations on the study area in 1980. This obvious downward 


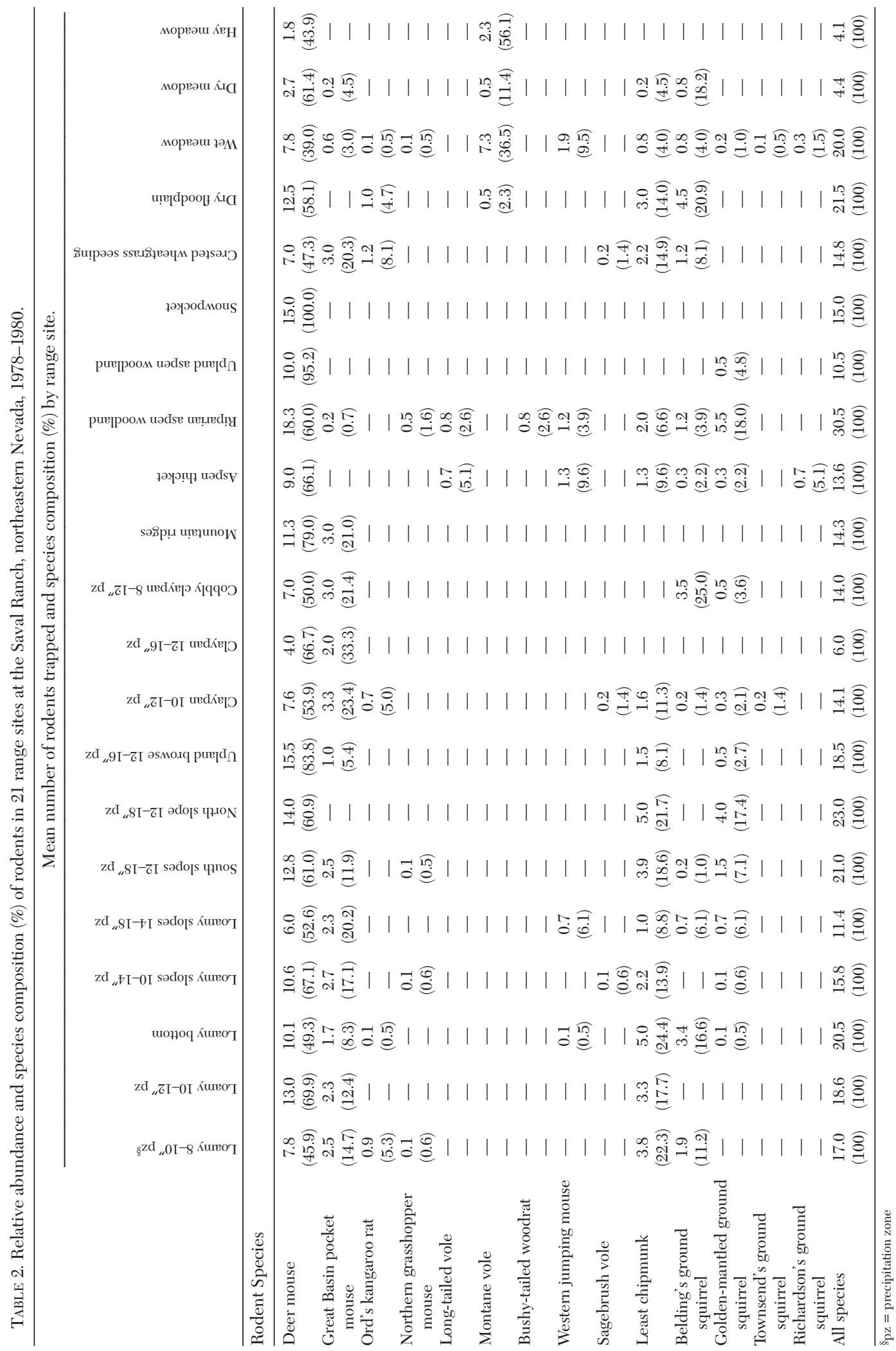


TABLE 3. Comparison of relative abundances (number per 100 trap-nights) of deer mice (Peromyscus maniculatus) in grouped range sites between years (1978-1979 versus 1980) at the Saval Ranch in northeastern Nevada. Number of traplines $(n)$ is given for each range site.

\begin{tabular}{|c|c|c|c|}
\hline \multirow[b]{2}{*}{ Range site } & \multicolumn{2}{|c|}{ Mean deer mice per trapline } & \multirow[b]{2}{*}{$\%$ Change } \\
\hline & $1978-1979$ & 1980 & \\
\hline \multicolumn{4}{|l|}{ BIG SAGEBRUSH SITES } \\
\hline Loamy $8-10^{\prime \prime} \mathrm{pz}{ }^{\S}$ & 9.2 & 5.3 & \\
\hline Loamy bottom & 11.2 & 4.0 & \\
\hline Loamy $10-12^{\prime \prime} \mathrm{pz}$ & 23.0 & 16.0 & \\
\hline Loamy slopes $10-14^{\prime \prime} \mathrm{pz}$ & 14.8 & 6.4 & \\
\hline Loamy slopes $14-18^{\prime \prime} \mathrm{pz}$ & 13.0 & 2.5 & \\
\hline South slopes $12-18^{\prime \prime} \mathrm{pz}$ & 17.2 & 5.6 & \\
\hline Composite mean & $14.7(n=22)$ & $6.6(n=17)$ & $-55^{*}$ \\
\hline \multicolumn{4}{|l|}{ MOUNTAIN BRUSH SITES } \\
\hline North slopes 12-18" pz & 14.0 & - & \\
\hline Upland browse $12-16^{\prime \prime} \mathrm{pz}$ & 8.0 & 23.0 & \\
\hline Composite mean & $11.0(n=2)$ & $23.0(n=1)$ & +109 \\
\hline \multicolumn{4}{|l|}{ LOW SAGEBRUSH SITES } \\
\hline Claypan 10-12" pz & 7.8 & 7.4 & \\
\hline Claypan $12-16^{\prime \prime} \mathrm{pz}$ & 4.0 & - & \\
\hline Cobbly claypan & - & 7.0 & \\
\hline Mountain ridges & - & 11.3 & \\
\hline Composite mean & $5.9(n=6)$ & $8.6(n=2)$ & +46 \\
\hline \multicolumn{4}{|l|}{ ASPEN SITES } \\
\hline Aspen thicket & 17.0 & 9.5 & \\
\hline Riparian aspen woodland & 30.0 & 6.5 & \\
\hline Upland aspen woodland & 24.0 & 5.3 & \\
\hline Composite mean & $23.7(n=4)$ & $7.2(n=7)$ & $-70^{*}$ \\
\hline SNOWPOCKET & $15.0(n=1)$ & - & - \\
\hline CRESTED WHEATGRASS & $8.7(n=3)$ & $4.5(n=2)$ & -48 \\
\hline DRY FLOODPLAIN & $12.5(n=2)$ & - & - \\
\hline WET MEADOW & $12.1(n=7)$ & $5.2(n=12)$ & $-57 *$ \\
\hline DRY MEADOW & $1.3(n=3)$ & $4.0(n=3)$ & +208 \\
\hline HAY MEADOW & $2.0(n=2)$ & $1.8(n=5)$ & -10 \\
\hline
\end{tabular}

$\S_{\mathrm{pz}}=$ precipitation zone

*The percent change between means within the row is significant $(P<0.05)$.

trend-reflected primarily in deer mice (Table 3) and, because of this species' high relative abundance, all species combined (Table 4)negates the use of 1980 traplines as replicates of those trapped during 1978-1979 in the same range sites. Of the 15 range sites trapped in both 1978-1979 and 1980, deer mouse populations were markedly lower (by $30 \%$ to $81 \%$ ) in 10 of these in 1980 (Table 3). This trend was also obvious for all species combined (Table 4).

For statistical analysis, we grouped the range sites dominated by big sagebrush, mountain brush species, low-growing sagebrush on claypan and cobbly soils (little, alkali, and black sagebrush, collectively called low sagebrush), and aspen (Tables 3,4). The 2 most heavily sampled composite range sites (big sagebrush and aspen), as well as the wet meadow range site, showed a significant decrease $(P<0.05)$ in deer mice (Table 3) and total rodent abundance (Table 4) in 1980. Lines in these sites made up $68 \%$ of the total number of traplines sampled during the inventory period.

\section{Density Comparisons among Habitats}

To better quantify rodent populations and test for significant differences among range sites, we calculated densities for range sites where several lines were trapped (1978-1979 only). In some cases, data obtained from 2 or more range sites were pooled to form a habitat type for meaningful statistical comparison as follows: the low elevation big sagebrush type was a combination of the loamy $8-10^{\prime \prime} \mathrm{pz}$ and loamy bottom range sites; the midelevation big sagebrush type included the loamy $10-12$ "pz and loamy slopes $10-14$ "pz range 
TABLE 4. Comparison of relative rodent abundance for all species combined in grouped range sites between years (1978-1979 versus 1980) at the Saval Ranch in northeastern Nevada. Number of traplines $(n)$ is given for each range site.

\begin{tabular}{|c|c|c|c|}
\hline \multirow[b]{2}{*}{ Range site } & \multicolumn{2}{|c|}{ Mean rodent individuals per trapline } & \multirow[b]{2}{*}{$\%$ Change } \\
\hline & 1978-1979 & 1980 & \\
\hline \multicolumn{4}{|l|}{ BIG SAGEBRUSH SITES } \\
\hline Loamy 8-10" pz & 20.4 & 12.7 & \\
\hline Loamy bottom & 22.5 & 9.0 & \\
\hline Loamy $10-12^{\prime \prime} \mathrm{pz}$ & 25.0 & 15.5 & \\
\hline Loamy slopes $10-14^{\prime \prime} \mathrm{pz}$ & 22.0 & 9.6 & \\
\hline Loamy slopes $14-18^{\prime \prime} \mathrm{pz}$ & 13.0 & 10.5 & \\
\hline South slopes $12-18^{\prime \prime} \mathrm{pz}$ & 24.8 & 19.8 & \\
\hline Composite mean & $21.3(n=22)$ & $14.6(n=17)$ & $-31 *$ \\
\hline \multicolumn{4}{|l|}{ MOUNTAIN BRUSH SITES } \\
\hline North slopes $12-18^{\prime \prime} \mathrm{pz}$ & 14.0 & - & \\
\hline Upland browse $12-16^{\prime \prime} \mathrm{pz}$ & 11.0 & 26.0 & \\
\hline Composite mean & $12.5(n=2)$ & $26.0(n=1)$ & +108 \\
\hline \multicolumn{4}{|l|}{ LOW SAGEBRUSH SITES } \\
\hline Claypan 10-12" pz & 13.8 & 14.3 & \\
\hline Claypan $12-16^{\prime \prime} \mathrm{pz}$ & 6.0 & - & \\
\hline Cobbly claypan & - & 14.0 & \\
\hline Mountain ridges & - & 14.3 & \\
\hline Composite mean & $9.7(n=6)$ & $14.2(n=2)$ & +46 \\
\hline \multicolumn{4}{|l|}{ ASPEN SITES } \\
\hline Aspen thicket & 22.0 & 9.5 & \\
\hline Riparian aspen woodland & 49.0 & 12.0 & \\
\hline Upland aspen woodland & 24.0 & 6.0 & \\
\hline Composite mean & $31.7(n=4)$ & $9.2(n=7)$ & $-71 *$ \\
\hline SNOWPOCKET & $15.0(n=1)$ & - & - \\
\hline CRESTED WHEATGRASS & $16.3(n=3)$ & $12.5(n=2)$ & -23 \\
\hline DRY FLOODPLAIN & $21.5(n=2)$ & - & - \\
\hline WET MEADOW & $37.6(n=7)$ & $9.8(n=12)$ & $-74^{*}$ \\
\hline DRY MEADOW & $3.3(n=3)$ & $5.3(n=3)$ & +61 \\
\hline HAY MEADOW & $3.0(n=2)$ & $4.6(n=5)$ & +53 \\
\hline
\end{tabular}

$\S_{\mathrm{pz}}=$ precipitation zone

*The percent change between means within the row is significant $(P<0.05)$.

sites; the mountain brush type was comprised of the loamy slopes $14-18^{\prime \prime} \mathrm{pz}$, south slopes $12-18^{\prime \prime} \mathrm{pz}$, steep north slopes $12-18^{\prime \prime} \mathrm{pz}$, and upland browse $12-16$ "pz range sites; and the low sagebrush type included the claypan $10-12^{\prime \prime} \mathrm{pz}$ and claypan $12-16$ "pz range sites (Table 5).

Calculated densities for each rodent species are listed in Table 5. Significant differences in density $(P<0.05)$ were obtained among some habitat types, especially for the more abundant species. Deer mouse densities were lowest in low-elevation big sagebrush, low sagebrush, and wet meadow habitat types, reaching significantly higher densities (8.1-10.0 deer mice per hectare) in the midelevation big sagebrush, mountain brush, and aspen types (Table 5). Densities of Great Basin pocket mice were significantly higher in the midelevation big sagebrush and low sagebrush habitats $(\sim 2$ per hectare). Ord's kangaroo rats occurred at relatively low densities and only in the low-elevation big sagebrush and low sagebrush habitat types, while northern grasshopper mice and bushy-tailed woodrats were caught only in aspen habitat, at 0.3 per hectare and 0.5 per hectare, respectively.

We caught montane voles only in the 2 habitat types with greatest herbaceous cover: the aspen and wet meadow habitat. Significantly higher density (11.2 voles per hectare) was recorded in the latter. Western jumping mice inhabited 3 habitat types at relatively low densities, and no significant differences $(P>0.05)$ in density were detected among the habitat types. Least chipmunk densities were relatively uniform among 5 habitat types but were significantly higher (1.3 per hectare) in the low elevation big sagebrush type. For all rodent species combined, highest densities 
Table 5. Densities of 12 rodent species in 6 habitats at the Saval Ranch, northeastern Nevada, 1978-1979 combined. Means with differing letters are significantly different $(P<0.05)$ from other means in same row. Number of trap lines $(n)$ in each habitat is given.

\begin{tabular}{|c|c|c|c|c|c|c|}
\hline \multirow[b]{2}{*}{ Species } & \multicolumn{6}{|c|}{ Rodent density (rodents $\cdot \mathrm{ha}^{-1}$ ) } \\
\hline & $\begin{array}{c}\text { Low elev. } \\
\text { big sage } \\
n=11\end{array}$ & $\begin{array}{l}\text { Mid-elev. } \\
\text { big sage* } \\
n=8\end{array}$ & $\begin{array}{c}\text { Mountain } \\
\text { brush }^{\dagger} \\
n=5\end{array}$ & $\begin{array}{c}\text { Low sage } \\
n=6\end{array}$ & $\begin{array}{c}\text { Aspen } \\
n=4\end{array}$ & $\begin{array}{c}\text { Wet } \\
\text { meadow } \\
n=7\end{array}$ \\
\hline Deer mouse & $4.7 \mathrm{c}$ & $10.0 \mathrm{a}$ & $8.1 \mathrm{ab}$ & $3.3 \mathrm{c}$ & $8.1 \mathrm{ab}$ & $5.8 \mathrm{bc}$ \\
\hline Great Basin pocket mouse & $1.1 \mathrm{~b}$ & $2.0 \mathrm{a}$ & $0.4 \mathrm{bc}$ & $1.9 \mathrm{a}$ & - & $0.2 \mathrm{c}$ \\
\hline Ord's kangaroo rat & $0.7 \mathrm{a}$ & - & - & $0.2 \mathrm{~b}$ & - & - \\
\hline Northern grasshopper mouse & - & - & - & - & 0.3 & - \\
\hline Montane vole & - & - & - & - & $0.3 \mathrm{~b}$ & $11.2 \mathrm{a}$ \\
\hline Bushy-tailed woodrat & - & - & - & - & 0.5 & - \\
\hline Western jumping mouse & $0.1 \mathrm{a}$ & - & - & - & $1.6 \mathrm{a}$ & $2.5 \mathrm{a}$ \\
\hline Least chipmunk & $1.3 \mathrm{a}$ & $0.3 \mathrm{~b}$ & $0.8 \mathrm{~b}$ & $0.2 \mathrm{~b}$ & $0.4 \mathrm{~b}$ & $0.3 \mathrm{~b}$ \\
\hline Belding's ground squirrel & $0.9 \mathrm{a}$ & - & - & $0.1 \mathrm{~b}$ & $0.2 \mathrm{~b}$ & - \\
\hline Golden-mantled ground squirrel & - & - & $0.5 \mathrm{a}$ & $0.2 \mathrm{a}$ & $1.4 \mathrm{a}$ & $0.1 \mathrm{a}$ \\
\hline Townsend's ground squirrel & - & - & - & $0.1 \mathrm{a}$ & - & $0.04 \mathrm{a}$ \\
\hline Richardson's ground squirrel & - & - & - & - & $0.1 \mathrm{a}$ & $0.2 \mathrm{a}$ \\
\hline Totals & $8.8 \mathrm{bc}$ & $12.3 \mathrm{~b}$ & $9.8 \mathrm{bc}$ & $6.0 \mathrm{c}$ & $12.9 \mathrm{~b}$ & $20.3 \mathrm{a}$ \\
\hline
\end{tabular}

\$Includes loamy 8-10" precipitation zone (pz) and loamy bottom pz.

"Includes loamy 10-12" pz and loamy slopes 10-14" pz.

†Includes loamy slopes 14-18" pz, south slopes 12-18" pz, steep north slopes 12-18" pz, and upland browse 12-16" pz.

Includes claypan 10-12" pz and claypan 12-16" pz.

were recorded in the wet meadow habitat type (Table 5), primarily as a function of the high density of montane voles.

\section{Discussion}

Our observaion of a preponderance of deer mice is corroborated by other small mammal studies conducted in predominantly sagebrush habitats (Borell and Ellis 1934, Linsdale 1938, Larrison and Johnson 1973, Feldhamer 1979, Hanley and Page 1982, McAdoo et al. 1986). Although deer mouse densities were statistically similar between sagebrush and meadow habitat during this study, a 5-year study in central Nevada showed that deer mice were 3 times more abundant in meadow habitat than adjacent upland (McAdoo et al. 1986). According to Larrison and Johnson (1973), deer mouse populations can increase by as much as a factor of 10 from 1 year to the next; these authors also concluded that deer mice are increasers as range condition becomes depleted. Kritzman (1974) reported that in big sagebrush habitat in Washington, deer mouse density increased in elevation, while pocket mice decreased, due primarily to edaphic factors. Hanley and Page (1982) compared grazed (mostly by cattle) with ungrazed pastures during 1 season in the sagebrush ecosystem of northwestern Nevada and concluded that deer mice, Great Basin pocket mice, and least chipmunks were all decreasers as conditions in xeric habitats declined but were increasers in mesic habitats.

The Great Basin pocket mouse, though not strictly a sagebrush obligate, has been reported as restricted to sagebrush communities in some areas of Utah (Fautin 1946). Feldhamer (1979) found this species restricted to sagebrush and greasewood (Sarcobatus sp.) communities in southeastern Oregon. However, the Great Basin pocket mouse does well in grassy habitats, even in areas dominated by introduced species like crested wheatgrass (Larrison and Johnson 1973). In the Saval Ranch area, we observed this species as very common in both sagebrushdominated habitat and crested wheatgrass seedings.

The least chipmunk, reported in 15 of 21 range sites in the Saval Ranch study area, is not considered a sagebrush obligate since it is also found in shadscale (Larrison and Johnson 1973) and greasewood communities (Feldhamer 1979). Within sagebrush habitats, McAdoo and Klebenow (1979) reported that the least chipmunk was spotty in distribution; however, Borell and Ellis (1934) indicated that this species was a characteristic mammal of big sagebrush-grass habitat in eastern Nevada, and 
Fautin (1946) reported that least chipmunks in western Utah occurred only in sagebrush communities. Larrison and Johnson (1973) reported that range depletion favored least chipmunks.

We caught relatively few northern grasshopper mice and bushy-tailed woodrats. Although fewer captures could indicate low populations, this may not necessarily be the case, especially for grasshopper mice. Larrison and Johnson (1973) also caught very few of these species in southern Idaho. They noted that the grasshopper mouse, a carnivore, could be expected to shun traps baited with rolled oats (as ours were). We caught western jumping mice in 5 range sites. This species is typically found in dense herbaceous vegetation (Larrison 1976).

Although we did not catch any western harvest mice during conventional trapping efforts in the 3-year study, we did catch 2 individuals of that species during 1980: 1 in a snap-trap and 1 in a live-trap, both in a loamy bottom range site dominated by sagebrush and basin wildrye (McAdoo and Klebenow 1982). Larrison and Johnson (1973) reported that harvest mice typically occur in dense grass habitats. They found highest numbers of this species in stands of basin wildrye and in crested wheatgrass seedings. They also indicated that western harvest mice are decreasers as range conditions become depleted, similar to the findings of Black and Frischnecht (1971).

Microtine rodents generally require dense herbaceous vegetation, with sagebrush voles occurring in the most xeric habitats occupied by microtines (O'Farrell 1974). We encountered relatively few sagebrush voles during our 3year study, trapping them only in habitats dominated by sagebrush-grass vegetation and in crested wheatgrass seedings. Although some consider this species to be a sagebrush obligate (Paige and Ritter 1999), Maser and Strickler (1978), working in southeastern Oregon, concluded that the sagebrush vole is not restricted to areas of sagebrush, but is opportunistic and can adapt to a variety of habitats within a given region during years of high population or beneficial habitat alteration. These authors indicated that grass cover, not sagebrush, is the limiting factor for sagebrush vole distribution; the species is found only in the best of rangeland areas and not on overgrazed, predominantly sagebrush-covered habitat. In northwestern Nevada, Oldemeyer et al. (1983) similarly concluded that sagebrush voles preferred areas with greater grass cover. Our documentation of sagebrush voles in crested wheatgrass seedings, as well as work by Larrison and Johnson (1973), suggests that this nonnative grass provides suitable habitat structure and forage for sagebrush voles. A similar relationship has been described for grass-nesting bird species in crested wheatgrass seedings (McAdoo et al. 1989).

We caught montane voles and long-tailed voles only in meadow-like and aspen-dominated range sites, respectively. During 39,200 trap-nights over an 8-year period in a followup study, McAdoo et al. (1986) trapped mountain voles in habitats other than meadows only during a cyclic population peak and only in habitats adjacent to meadows. Feldhamer (1979) and Clark (1973) reported a similar affinity of this species for meadow-like habitats. Hanley and Page (1982) reported that microtine rodents, because they rely on herbaceous cover, were decreasers as habitat conditions decline.

We compared our population estimates to those reported for similar habitats in studies where the measurement units are comparable. The relative abundance indices (individuals per 100 trap-nights) for deer mice, Great Basin pocket mice, and Ord's kangaroo rats reported in our 3-year study are within the confidence limits of those reported for southern Idaho by Larrison and Johnson (1973) for sagebrush and crested wheatgrass seedings during a 5-7-year sampling period. Our abundance estimates for least chipmunks were somewhat higher than those reported in this Idaho study. The density estimates (individuals per hectare) for deer mice, Great Basin pocket mice, and least chipmunks in sagebrush habitats during our study fell largely within the estimates produced by Feldhamer (1979) for sagebrush habitats during a 3-year study in southeastern Oregon, although our density estimates for pocket mice were somewhat lower. Density estimates for deer mice and least chipmunks calculated for sagebrush and aspen habitats during our 3year study were similar to those reported for similar habitats by Grant (1986) during 7 years of sampling in Utah. Our calculated density estimates for montane voles in meadow habitats were somewhat higher than those reported by Grant, and our Ord's kangaroo rat densities were lower.

Hannson (1967) and Petticrew and Sadlier (1970) reported that rodent abundance indices 
(total number of captures) are usually highly correlated with densities. Similarly, Slade and Blair (2000) concluded that the simple counts commonly used in studies of mammalian populations tend to underestimate population size, but are proportional to estimated numbers within a species and as such are indices of density. However, the authors also cautioned that these indices are not appropriate for interspecific comparisons of abundance (Slade and Blair 2000).

\section{Conclusions}

Based on our 3-year study and in comparison with the few other multiple-year studies of rodents in the sagebrush ecosystem, we conclude that the species composition and relative abundance / density of rodent species are variable within various habitats in the sagebrush ecosystem. McAdoo et al. (2004a) concluded that the inherent site potential of a given vegetation community, combined with variables such as the interspersion of varying shrub height and canopy cover, as well as herbaceous species composition, cover, and diversity, influence the diversity and abundance of wildlife species. The diverse rodent species within the sagebrush ecosystem have commensurately diverse habitat requirements. Although some species are more generalistic and adaptable (e.g., deer mice), others have more specific habitat needs (e.g., montane voles). Vegetation management for biological diversity on a landscape scale should take these diverse habitat requirements into consideration.

As researchers evaluate the effects of livestock grazing management and other vegetation management treatments on rodents, they need to be aware that the natural oscillations of rodent populations could easily be mistaken for the results of a treatment. Johnson (1982) had difficulty separating treatment differences from natural variation while trying to measure the impacts of livestock grazing on small mammals in southern Idaho. He recommended that studies be conducted with replication and strict controls before correlated data should be accepted as indicators of cause and effect relationships. Rosenstock (1996), working in south central Utah, similarly concluded that small mammal community composition varied greatly among sites and within treatments. We agree with Johnson's (1982) suggestion that the dy- namic changes in small mammal populations should be monitored over time and compared with controls to determine whether treatment impacts on natural populations are significant.

\section{Literature Cited}

Armentrout, D.J., And M.R. Barrington. 1980. A multiple resource inventory for multiple use land management decisions. Cal-Neva Wildlife Transactions 1980:92-99.

Black, H.L., AND N.C. Frischnecht. 1971. Relative abundance of mice on seeded sagebrush-grass range in relation to grazing. USDA Forest Service Research Note INT-147. 7pp.

Borell, A.E., AND R. ELLIS. 1934. Mammals of the Ruby Mountains region of northeastern Nevada. Journal of Mammalogy 15:12-44.

Brant, D.H. 1962. Measures of the movements and population densities of small rodents. University of California Publications in Zoology 62:105-184.

Clark, T.W. 1973. Local distributions and interspecies interactions in microtines, Grand Teton National Park, Wyoming. Great Basin Naturalist 33:205-217.

Fautin, R.W. 1946. Biotic communities of the northern desert shrub biome in western Utah. Ecological Monographs 16:251-310.

FeldhameR, G.G. 1979. Vegetative and edaphic factors affecting abundance and distribution of small mammals in southeastern Oregon. Great Basin Naturalist 39:207-218.

Grant, C.V. 1986. Wildlife distribution and abundance on the Utah Oil Shale Tracts 1974-1984. Great Basin Naturalist 46:469-507.

Hanley, T.A., and J.L. Page. 1982. Differential effects of livestock use on habitat structure and rodent populations in Great Basin communities. California Fish and Game 68:160-173.

Hansson, L. 1967. Index line catches as a basis of population studies of small mammals. Oikos 18:261-276.

Hayne, D.W. 1949. Two methods for estimating population from trapping records. Journal of Mammalogy 30:399-411.

Johnson, M.K. 1982. Response of small mammals to livestock grazing in southcentral Idaho. Journal of Range Management 35:51-53.

Kritzman, E.B. 1974. Ecological relationships of Peromyscus maniculatus and Perognathus parvus in eastern Washington. Journal of Mammalogy 55:172-188.

Larrison, E.J. 1976. Mammals of the Northwest. Seattle Audubon Society. Seattle, WA. 256 pp.

LaRrison, E.J., AND D.R. Johnson. 1973. Density changes and habitat affinities of rodents of shadscale and sagebrush associations. Great Basin Naturalist 33: 255-264.

LinsDALE, J.M. 1938. Environmental responses of vertebrates in the Great Basin. American Midland Naturalist 19:1-206.

Maser, C.W., AND G.S. Strickler. 1978. The sage vole, Lagurus curtatus, as an inhabitant of subalpine sheep fescue, Festuca ovina, communities on Steens Mountain-an observation and interpretation. Northwest Science 52:276-284.

McAdoo, J.K., G.N. BACK, M.R. BARRINGTON, AND D.A. KLEBENOW. 1986. Wildlife use of lowland meadows 
in the Great Basin. Transactions of the North American Wildlife and Natural Resources Conference 51:310-319.

McAdoo, J.K., AND D.A. KLEbenow. 1979. Native faunal relationships in sagebrush ecosystems. Pages 50-61 in Proceedings of the Sagebrush Ecosystem Symposium. Utah State University, Logan.

. 1982. Nongame wildlife research. Pages 140-151 in Progress Report-Saval Ranch Research and Evaluation Study.

McAdoo, J.K., W.S. LONGLAND, and R.A. Evans. 1989. Nongame bird community responses to sagebrush invasion of crested wheatgrass seedings. Journal of Wildlife Management 53:494-502.

McAdoo, J.K., S.R. Swanson, B.W. Schultz, and P.F. BRUSSARD. 2004a. Vegetation management for sagebrush-associated wildlife species. Pages 189-193 in A.L. Hild, N.L. Shaw, S.E. Meyer, T. Booth, and E.D. McArthur, compilers, Seed and soil dynamics in shrubland ecosystems, Laramie, Wyoming. Proceedings RMRS-P-31. USDA Forest Service, Rocky Mountain Research Station.

McAdoo, J.K., L.T. Vermeire, and W. Gilgert. 2004b. The other grazers: the interactions of "non-charismatic" microfauna in rangelands. Rangelands 26:3037.

O'FARRELL, M.H. 1974. Seasonal activity patterns of rodents in a sagebrush community. Journal of Mammalogy 55:809-823.

Oldemeyer, J.L., S.J. Martin, and S.G. Woodis. 1983. A preliminary report on the effects of a deferred-rotation grazing system on wildlife at the Sheldon National Wildlife Refuge. Cal-Neva Wildlife Transactions 1983: $26-42$.

Paige, C., AND S.A. RitTer. 1999. Birds in a sagebrush sea: managing sagebrush habitats for bird communities. Partners in Flight Working Group, Boise, ID.

Petticrew, B.G., and R.M. Sadlier. 1970. The use of index trap lines to estimate population numbers of deer mice (Peromyscus maniculatus) in a forest environment in British Columbia. Canadian Journal of Zoology 48:385-389.

Ports, M.A., AND J.K. McAdoo. 1986. Sorex merriami (Insectivora: Soricidae) in eastern Nevada. Southwestern Naturalist 31:415-416.

Rosenstock, S.S. 1996. Shrub-grassland small mammal and vegetation responses to rest from grazing. Journal of Range Management 49:199-203.

Slade, N.A., AND S.M. Blair. 2000. An empirical test of using counts of individuals captured as indices of population size. Journal of Mammalogy 81:1035-1045.

TuELler, P.T. 1975. The natural vegetation of Nevada. Mentzelia 1: 3-6, 23-28.

WEST, N.E. 1983. Western Intermountain sagebrush steppe. Pages 351-374 in N.E. West, editor, Temperate deserts and semi-deserts. Ecosystems of the world. Volume 5. Elsevier. New York. 522 pp.

Received 14 January 2005 Accepted 7 October 2005 